\title{
Sectoral Analysis of the Participation of the Public and Private Agents in the Production Activities in Egypt: An Efficiency Perspective
}

\author{
Dr. Ashraf Helmy \\ Associate Professor of Economics \\ Egyptian Chinese University \\ Faculty of Economics and International Trade \\ Cairo, Egypt \\ ahelmy@ecu.edu.eg
}

\begin{abstract}
This study aims at examining the efficiency of the participation of the public and private agents in the production process in different productive sectors of the Egyptian economy during the period 2003-2018. The study utilized the Stochastic Frontier Analysis (SFA), also known as the Composed Error model, to determine the efficiency of a production function that consists of labor and capital, as inputs, and the generated value-added by the two productive economic agents, as outputs.

The study found differentiated results across the productive sectors regarding the relative weights of the public and private agents and the efficiency of their technical performance, on the one hand, and the returns and contributions of labor and capital factors by the two economic agents in the productive sectors, on the other hand. The relative weak contribution of the public agents in the agriculture sector is commensurate with the low efficiency of their technical performance, and the sector is dominated by the private agents, which are relatively technically more efficient. Despite the technical performance of the private and public agents is almost equivalent in both the mining and manufacturing sectors; however, the public agents dominate the mining sector, while the private agents dominate the manufacturing sector. Regarding the services sector, the private agents perform with a relatively high level of technical efficiency and dominate the sector. In general, the study found that the relative weights of the public and private agents in different productive sectors in Egypt are, to a large extent, commensurate with their level of technical efficiency.
\end{abstract}

Keywords: Stochastic Frontier Analysis, Sectoral Analysis, Technical Efficiency, Egypt.

JEL: E23, L11, L25, P17.

\section{Introduction}

\section{Overview}

The problem of scarcity and the concept of rationality enforce shedding light on the efficient use of the available resources to reach the desired development goals, whether on the micro and/or macro levels. Under the umbrella of good governance, the process of economic growth is mainly supported by the concept of efficiency, whether through the process of allocating factors of production and/or the efficiency of utilizing these resources (UN Millennium Project, 2005). Good governance provides a better economic environment surrounding the business framework, supports the social and physical infrastructure that enhances the ef-

* This article was submitted in April 2021, and accepted for publishing in August 2021.

(C) Arab Administrative Development Organization- League of Arab States, 2025, pp 227-242، DOI: 10.21608/aja.2021.72642.1076 
ficiency of productive agents, and enables efficient management of the resource endowment of a country (Hall and Jones, 1999; Shah and Huther, 1998). In a mixed economic system, the private and public productive agents are both responsible for the task of utilizing the available resources; thus, they bear the responsibility for the efficiency of utilizing these resources. In other words, the public and private economic agents are responsible for the efficiency of the production process in the economy. Empirically, the relative weights of the two productive players or agents vary from one country to another, and within one country, from one productive sector to another; however, the relative weights of the two players are not necessary as much as the efficiency at which each one performs its productive role. Based on the belief that the sizeable public sector impedes the economic growth process, some arguments oppose the increase in the size of the public sector in the economy (Fölster and Henrekson, 2001), while others argue that there are no certain answers regarding the effect of the size of the public sector on the process of economic growth, where this depends on several controlled variables such as the features and characteristics of each economic agent and the efficiency introduced by each one (Agell et al., 1997). The absence of competition and all types of incentives and motives in the public sector, relative to the private one, come on top of the public agents' characteristics that support the minimization of its size in the economy (Bogolib, 2013). On the other hand, the efficient participation of public agents may complement the work of the private ones by improving the efficiency of allocating resources to the appropriate productive sectors, accelerating the capital accumulation process, and introducing new high-cost technologies and productive techniques (Alam et al., 2017). Moreover, the public sector is considered the main provider of business and social services in the economy; so that changing the size and productivity of the public sector may have further implications on the performance of the economy as a whole (Thornhill, 2006). On the other side, the private agents have an important development role to play in the economy through the processes of job creation, the size of the exports, and the volume of tax revenue (Bella et al. 2013). The absence of efficiency in the private agents may impede their development role and ultimately leads to exit from the business sphere. Accordingly, it can be said that the concept of efficiency is the governor factor in determining and assessing the size of each economic agent in the economy.

\section{Study Problem}

History has witnessed an exchange in the economic roles of both the public and the private sectors, where several services and goods that previously have been provided by the private sector are now typically provided by public agents, while a number of public activities were subject to privatization (Quiggin, 1999). The changes in the economic roles raised a question regarding the relative efficiency of both the private and public economic agents across different productive sectors in the economy to assess and determine the optimal size of each agent in each economic sector. Therefore, an analysis based on this implicit question may lead to a better understanding of the optimal weight of each economic agent based on the efficiency of its performance.

\section{Study Objectives and Layout}

This study tries to examine the efficiency of running the production function by the public and private economic agents in the four main productive sectors in the Egyptian economy to assess how appropriate is the weight of each economic agent relative to the efficiency of its performance in the different economic sectors. Figure (1) depicts the study layout.

Figure (1) illustrates that the study will try to examine the technical efficiency of performing the production function that consists of labor and capital, as inputs, and value-added, as output, by the two productive economic agents, the private and public ones, in four productive economic sectors, namely agriculture, mining, manufacturing, and services sectors. The analysis will reveal the relative weight and production technical efficiency of both the private and public agents in the various productive sectors in the Egyptian 
economy. Therefore, it is possible to determine the extent to which the relative weight of each productive agent is proportional to its technical efficiency in the various productive sectors.

\section{Study Hypothesis}

The weights of the public and private agents in the different productive sectors in Egypt are commensurate with their levels of technical efficiency.

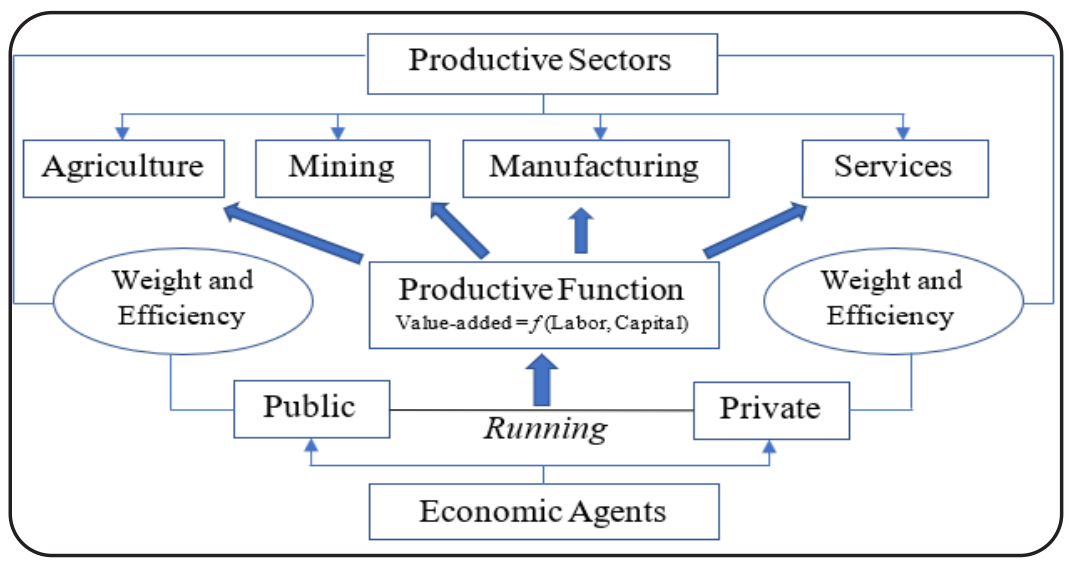

Figure (1): The Study Layout

\section{Study Methodology}

This study utilizes the Stochastic Frontier Analysis (SFA) to determine the efficiency of a production function that consists of labor and capital, as inputs, and the generated value-added, as outputs. The stochastic model, also known as the Composed Error model, captures two types of errors; the first one is the symmetric error term or standard noise term, while the second one is the one that results from the technical inefficiency in the production process. In other words, the Stochastic Frontier Analysis captures the deviation from the optimum limit or the frontier due to the noise error and the technical inefficiency.

\section{The Scope of the Study}

This study examines the efficiency of technical production performance of the public and private agents in the main productive sectors in the Egyptian economy, namely agriculture, mining, industrial, and services sectors, through the period 2003-2018.

\section{Sources of Data}

Data are collected from two main sources, the Central Agency for Public Mobilization and Statistics (CAPMAS), Employment, Wages and Working Hour Bulletin, and Ministry of Planning and Economic Development.

\section{Research Plan}

- Section (1): Introduction.

- Section (2): Literature Review.

- Section (3): The Development of the Size of Public and Private Agents and their Contributions to Different Economic Sectors in Egypt.

- Section (4): The Technical Efficiency Analysis.

- Section (5): Concluding Remarks and Recommendations.

\section{Literature Review}

This section illustrates the theoretical and empirical literature regarding the participation, efficiency, and performance of public and private economic agents in different economies. 
There are meaningful pieces of theoretical literature that oppose the increasing size and participation of the public agents in the economy, based on their modest or even low efficient performance due to the lack of all types of incentives (Demsetz,1967; Pejovich, 1969). Leibenstein (1966) argues that the inefficiency in the performance of public agents is attributed to their monopoly power. Baumol (1967) argues that the wages of labor in the public sector do not match their levels of productivity, where these wages are usually adjusted to the wages in the private sector, which, in most cases, represent relatively higher levels of productivity. Orzechowski (1977) and Mueller (1987) argued that public agents are usually producing beneath their production possibilities frontier, where they are suffering from technical inefficiency in performing the production processes.

Part of the empirical studies agrees with the previous theoretical literature, while the findings of other studies oppose these claims. The study of Landau (1983) applied cross-sectional analysis on 19 countries and found a negative impact of the size of the public sector on the rate of economic growth. The study of Aschauer (1989) examined the productivity of public expenditure in the USA through the period 19451985 , using the ordinary least squares regression analysis, and argued that the public capital, which is not directed to military purposes, is considered a productive expenditure. The study of Munnell (1990) agreed with the findings of Aschauer (1989); however, the study illustrated that the response of aggregate output to capital is very low and lies within the range of 0.06-0.15. The study of Evans and Karras (1994) applied panel data analysis on annual data extracted from the USA, through the period 1970-1986, and argued that public expenditure on education is the only productive expenditure. The study of Bergh and Henrekson (2011) applied panel data analysis on a number of European countries to examine the relationship between the size of government and economic growth performance. The study found that there is no certain tradeoff relationship between economic growth and government size. The study of Afonso and Jalles (2011) examined the relationship between government size and institutional quality using panel data analysis on data of 108 countries during the period 1970-2008. The study concluded that, in general, the size of the government, and government consumption, in particular, affects economic growth negatively, while the level of institutional quality positively affects the level of per-capita income. Based on normal distribution techniques. The study of Ekinci (2011) tried to determine the optimal size of the public sector, represented by the percentage of public expenditure to GDP, in the economy. The study argued that the rate of public expenditure to GDP is at its minimum level at the rate of $4.55 \%$, and this rate should not exceed the rate of $31.7 \%$, while the optimum rate is set at $13.4 \%$. The study of García-Sánchez et al. (2013) applied panel data analysis on data collected from 202 countries during the period 2002-2008 to determine the source of government effectiveness and argued that organizational environment is the main representable of government effectiveness, as it has a powerful effect on the process of economic development and the educational status. The study of Soriano and Garrido (2015) applied panel data analysis on 52 countries through the period 1995-2011 to determine the extent of the necessity of public sector intervention in the economy. The study argued that as long as the level of income is low in one country, the intervention of the public sector becomes more necessary for the interest of economic development. The study of Harb and Hall (2017) tried to determine the relationship between the size of the government and economic growth and applied panel data analysis for a sample of five countries in the middle east and North Africa region during the period 19702014. The study found that below a certain level of government size (18\% of GDP) the effect of government will be negative on the level of economic growth. The study of Lovre et al. (2017) examined the efficiency of the public sector in nineteen developed countries and argued that countries with large public sectors perform better than countries with relatively small ones. Moreover, the study argued that the concept of New Public Management, a concept that is newly introduced by the International Monetary Funds and the World Bank, does not add too much to the issue of economic welfare. The study of Monte (2017) applied dynamic panel model to examine the behavior of labor in both the public and private companies in Mexico during the 
period 2003-2012 and argued that the compliance, effort, and loyalty of labor to work in the private companies are relatively higher than in the public ones. The study of Nyasha and Odhiambo (2019) applied the Granger-causality approach to determine the relationship between the size of the public sector and the economic growth in a sample of developed and developing countries and argued that there is no specific and clear answer to determine this relationship, where there are many factors stand behind this relationship such as the degree of development of the country under study, the adopted methodology, proxies, data set used, and the considered period. Based on the specifications of the Scully model and the quadratic equation model. The study of Husseiny (2019) examined the effect of the size of the public sector on the process of economic growth in Egypt during the period 1982-2015. The study concluded that the size of the public sector is considered a suitable one in Egypt, where it supports the process of economic growth in the Egyptian economy.

\section{What is New with this Study?}

First, this study determines the relative weights of public and private agents in different productive sectors in Egypt based on the number of companies, the number of labor, the amount of capital, and the generated value-added in the various productive sectors by the two economic agents. Secondly, the study tries to examine the technical efficiency of performing a production function that consists of labor and capital, as inputs, and the generated value-added, as outputs, and determines how the generated value-added responds to the number of labor and the amount of capital. Finally, the study tries to assess how appropriate is the weight of each economic agent relative to the efficiency of its technical production performance in the different economic sectors.

\section{The Development of the Size of Public and Private Agents and their Contributions to Different Economic Sectors in Egypt.}

\section{The Agriculture Sector}

At the beginning of the study period, the number of private companies dominated the number of companies in the agriculture sector with more than 600 private companies, while the public sector was represented by just 22 public companies. In 2008, the number of private companies retreated to 69 companies while the number of public ones increased to 63 companies and the two agents shared control over the sector with a limited number of companies, see figure (2), panel (a). Regarding the number of labor factors in the agriculture sector, the private sector was the main employer of labor, where it employed $72 \%$, on average, of total agricultural labor during the study period, see panel (b).

Panel (a)

Number of Working Companies

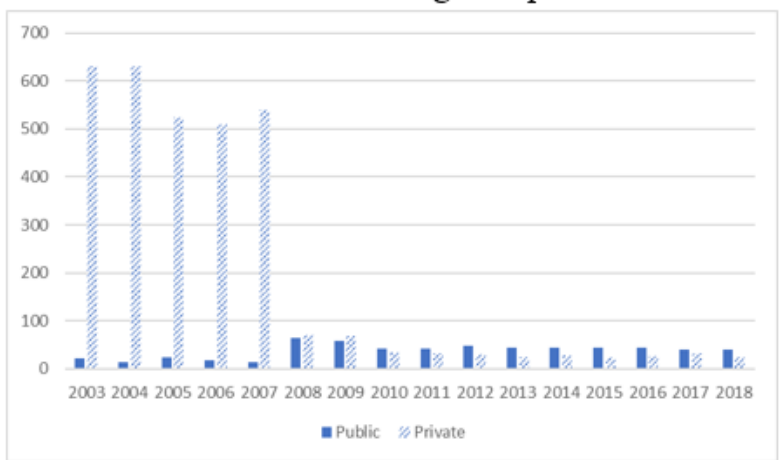

Panel (b)

Number of Labor-Factor

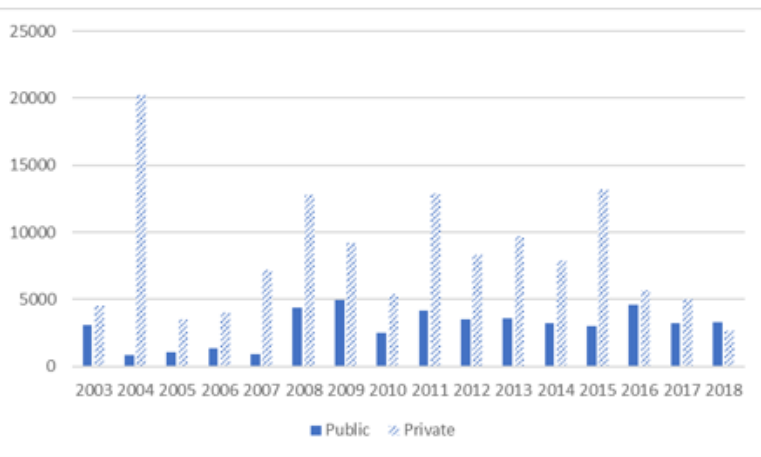

Source: Central Agency for Public Mobilization and Statistics (CAPMS), Employment, Wages and Working Hour Bulletin, different editions. 
The cost of labor factor in the public companies was higher than their costs in the private ones by almost $30 \%$, where the average wage per week in the public and private agents recorded 414 EGP and 320 EGP, respectively, during the study period, see figure (3).

The private sector utilized about $58.5 \%$, on average, of the total capital devoted to the agriculture sector while the public sector occupied $41.5 \%$, on average, of total capital. On the other hand, the value-added generated by the public companies was limited to just $0.05 \%$, on average, of the total value-added generated in the

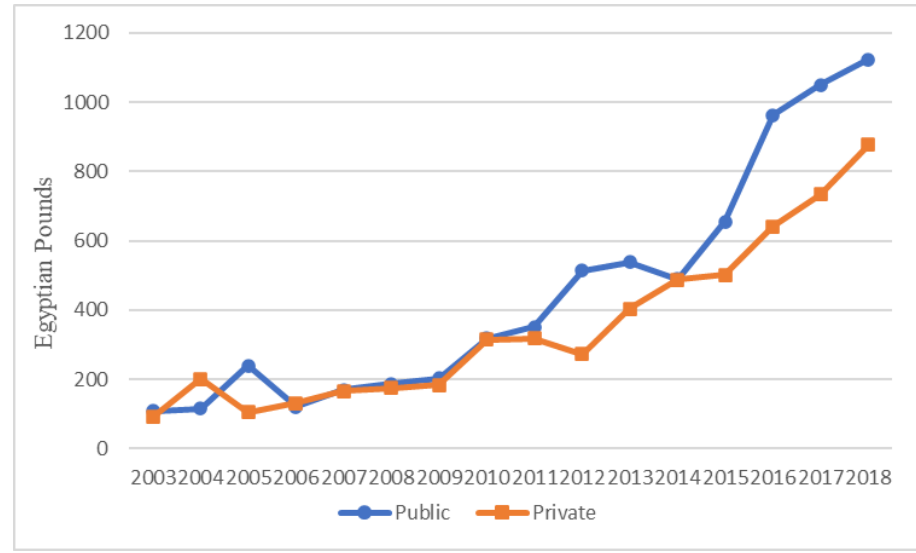

Source: Central Agency for Public Mobilization and Statistics (CAPMS), Employment, Wages and Working Hour Bulletin, different editions.

Figure (3): The Average Wage per Week in the Agriculture Sector agriculture sector, see figure (4), panel (b). In addition, the growth of value-added in the private companies was significantly stable relative to the public ones, where the average growth rates of the value-added generated by the public and private companies during the study period were $28 \%$ and $15 \%$, with standard deviations of $74 \%$ and $7 \%$, respectively. What is worth noting is the significant shift of public and private capital towards the agricultural sector in 2018.

Panel (a)

Amount of Capital

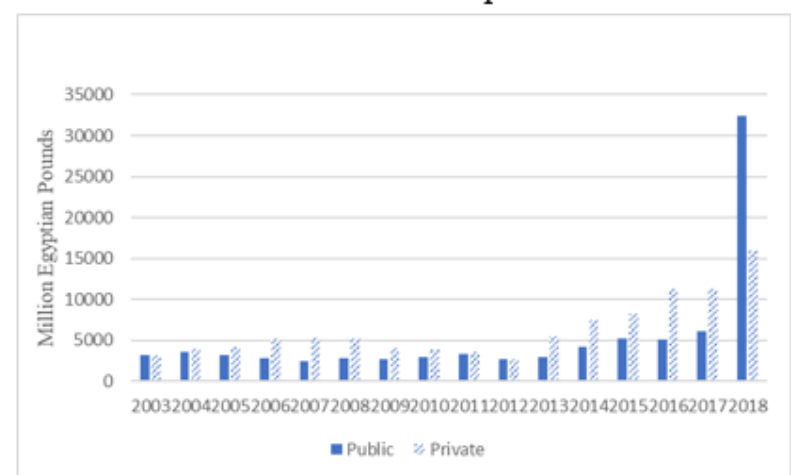

Panel (b)

Generated Value-Added

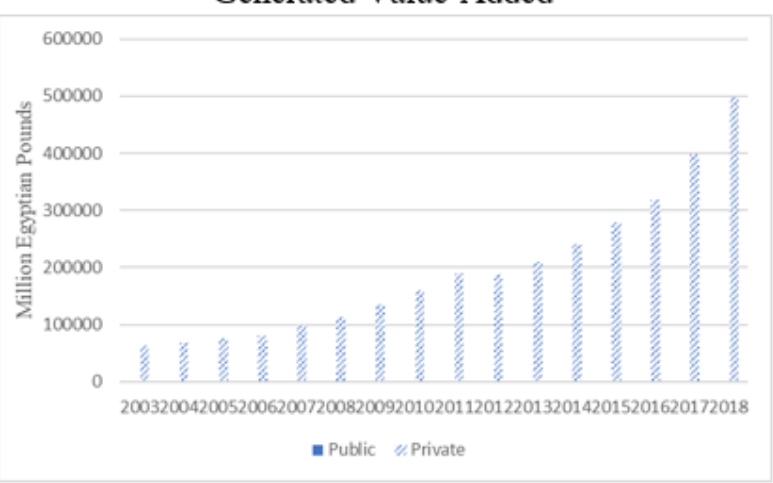

Source: Ministry of Planning and Economic Development.

Figure (4): The Amount of Capital and the Generated Value-Added in the Agriculture Sector

\section{The Mining Sector}

The number of public companies in the mining sector has been developed through the study period and dominated the number of companies in the mining sector with sixteen companies, while the number of the private companies have been significantly deteriorated and recorded just five companies at the end of the study period. The development of the number of public companies has been associated with occupying a relatively large number of labor factors by the public companies, where they occupied $60 \%$, on average, of the total labor in the mining sector, see figure (5).

The cost of labor factor in the private companies has exceeded its costs in the public ones by $40 \%$, where the average wage per week in the public and private agents recorded average wage rates of 713 EGP and $1100 \mathrm{EGP}$, respectively, during the study period, see figure (6). 
Panel (a)

Number of Working Companies

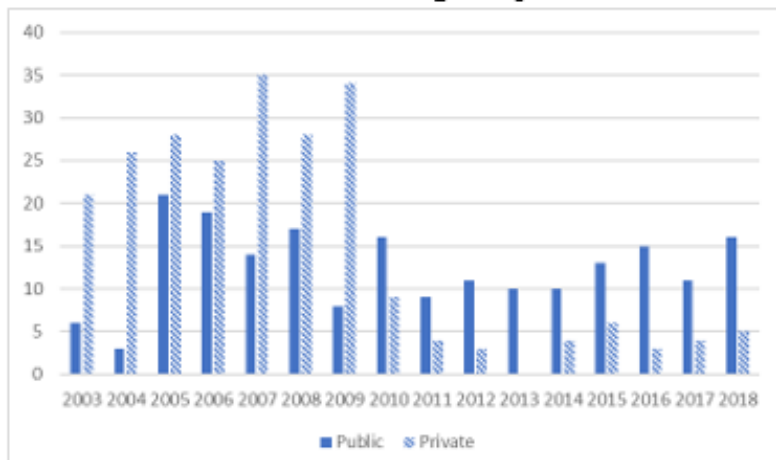

Panel (b)

Number of Labor-Factor

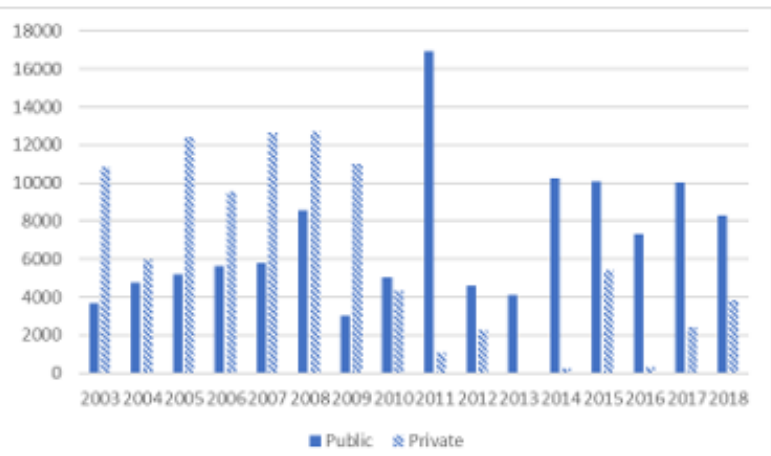

Source: Central Agency for Public Mobilization and Statistics (CAPMS), Employment, Wages and Working Hour Bulletin, different editions.

Figure (5): The Number of Companies and Labor factor in the Mining Sector

The public sector utilized about $32 \%$, on average, of the total capital in the mining sector and contributed to $80 \%$, on average, of the total value-added generated by the sector, see figure (7). The average growth rates of the value-added generated by the public and private companies in the mining sector recorded $19 \%$ and $24 \%$, with standard deviations of $24 \%$ and $23 \%$, respectively, during the study period.

\section{The Manufacturing Sector}

Despite the deterioration in the number of companies in the manufacturing sector; however, the private companies

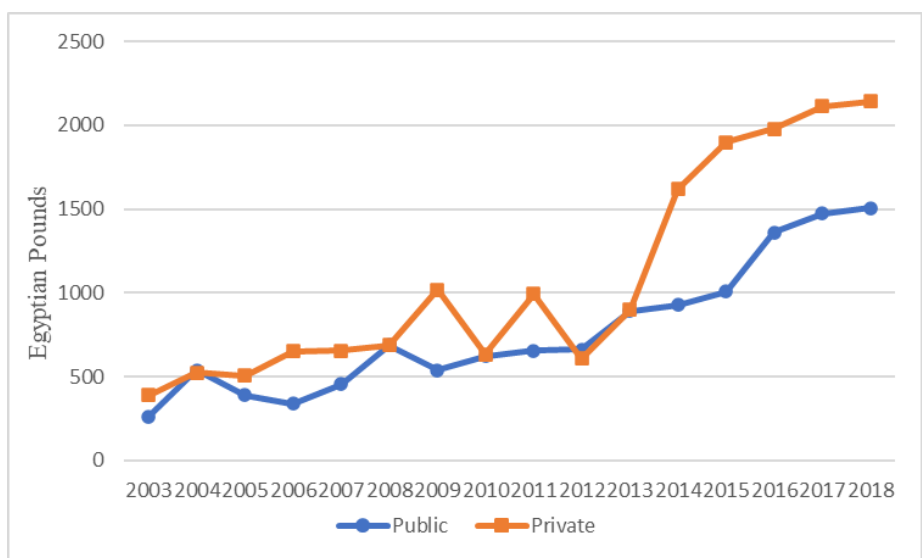

Source: Central Agency for Public Mobilization and Statistics (CAPMS), Employment, Wages and Working Hour Bulletin, different editions.

Figure (6): The Average Wage per Week in the Mining Sector dominated the number of companies in the manufacturing sector by $85 \%$, on average, of the working companies during the study period. Moreover, the private companies employed around $60 \%$, on average, of the total labor devoted to the manufacturing sector, see figure (8).

Panel (a)

Amount of Capital

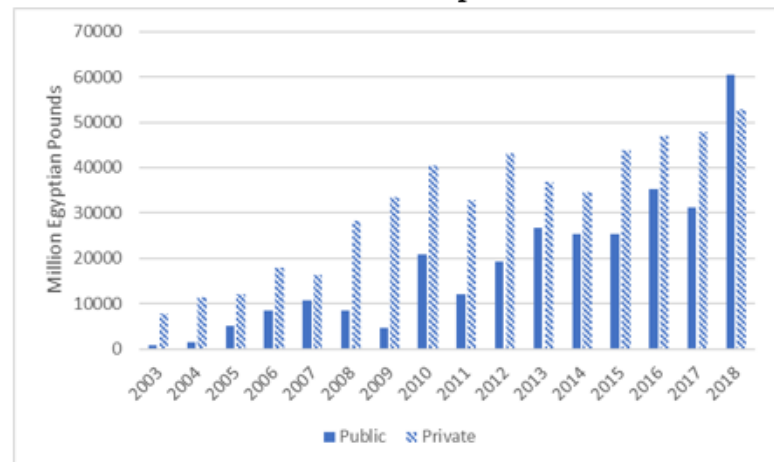

Panel (b)

Generated Value-Added

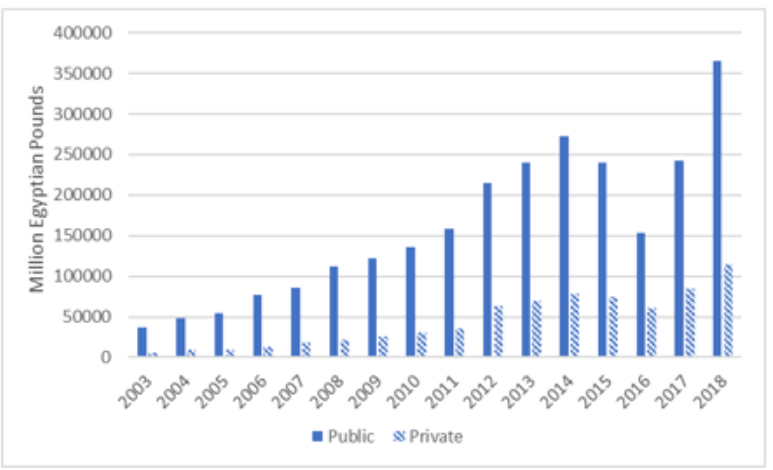

Source: Ministry of Planning and Economic Development.

Figure (7): The Amount of Capital and the Generated Value-Added in the Mining Sector 
Panel (a)

Number of Working Companies

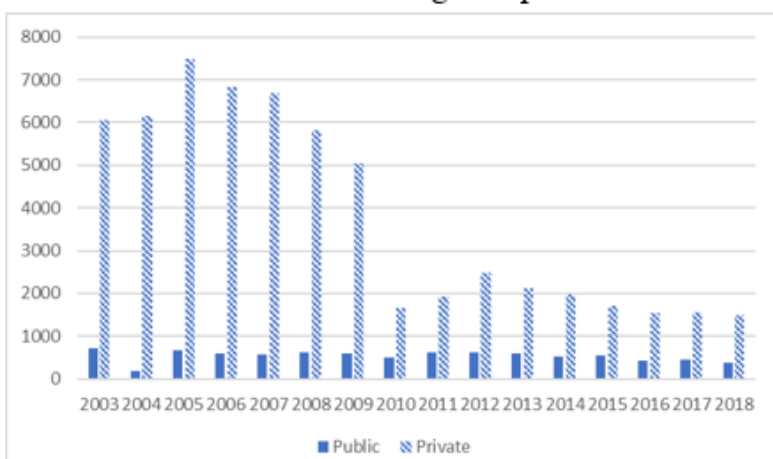

Panel (b)

Number of Labor-Factor

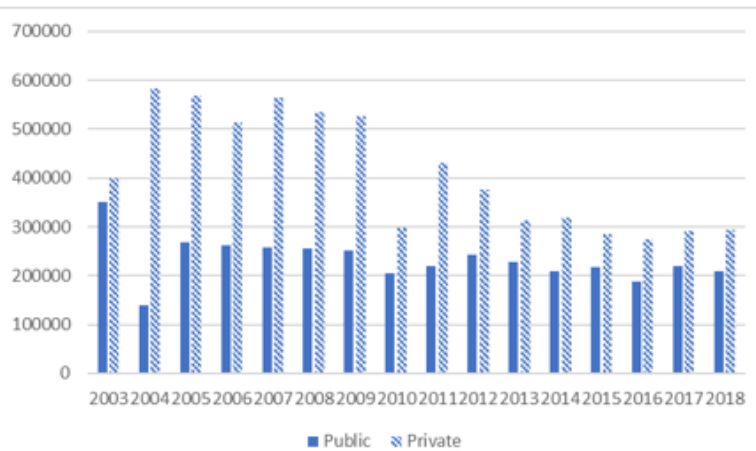

Source: Central Agency for Public Mobilization and Statistics (CAPMS), Employment, Wages and Working Hour Bulletin, different editions.

Figure (8): The Number of Companies and Labor factor in the Manufacturing Sector

During the study period, the cost of labor factor in the public companies exceeded their costs in the private ones by almost $47 \%$, where the average wage per week in the public and private agents recorded average rates of $460 \mathrm{EGP}$ and 313 EGP, respectively, during the study period, see figure (9).

The private agents utilized around $75 \%$, on average, of total capital in the manufacturing sector and produced $78 \%$, on average, of the total value-added generated by the manufacturing sector, see figure (10). Despite the growth rate of the value-added generated by the public agents is high-

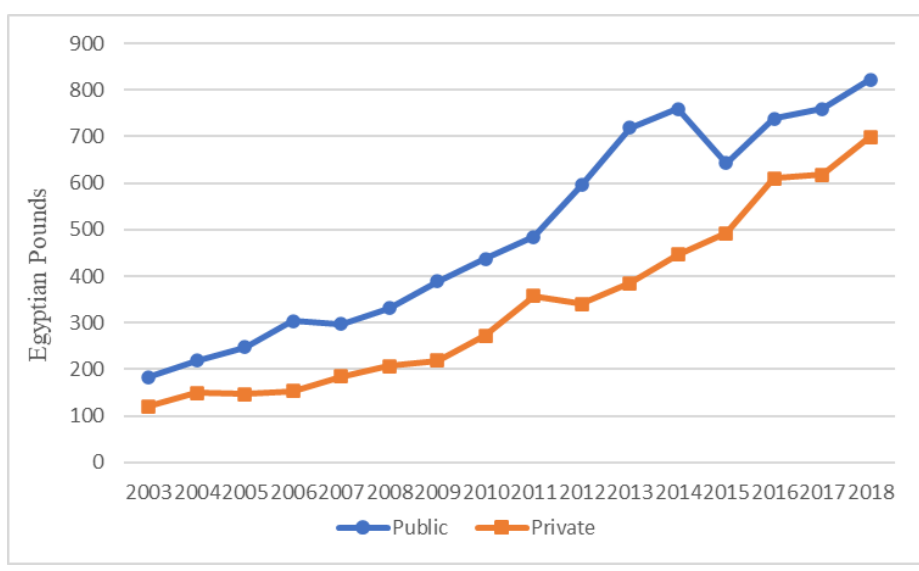

Source: Central Agency for Public Mobilization and Statistics (CAPMS), Employment, Wages and Working Hour Bulletin, different editions.

Figure (9): The Average Wage per Week in the Manufacturing Sector er than the one generated by the private agents; however, the rate of growth was more stable in the private sector relative to the public one, where the average growth rates of the value-added generated by the public and private companies in the manufacturing sector recorded $25 \%$ and $15 \%$, with standard deviations of $34 \%$ and $7 \%$, respectively, during the study period. Panel (a)

Amount of Capital

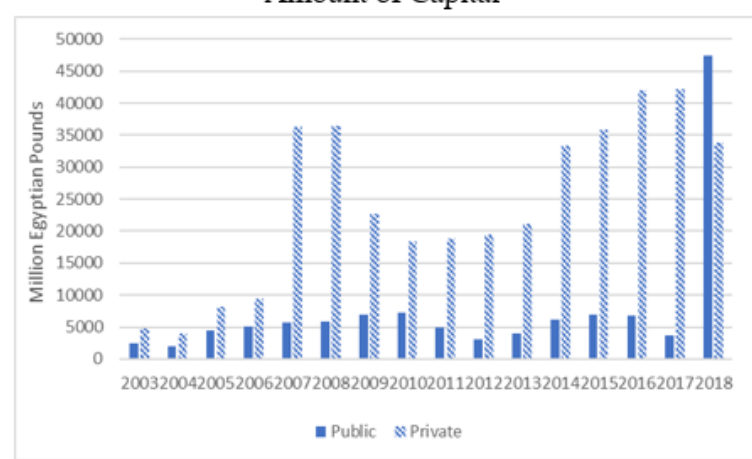

\section{Panel (b)}

Generated Value-Added

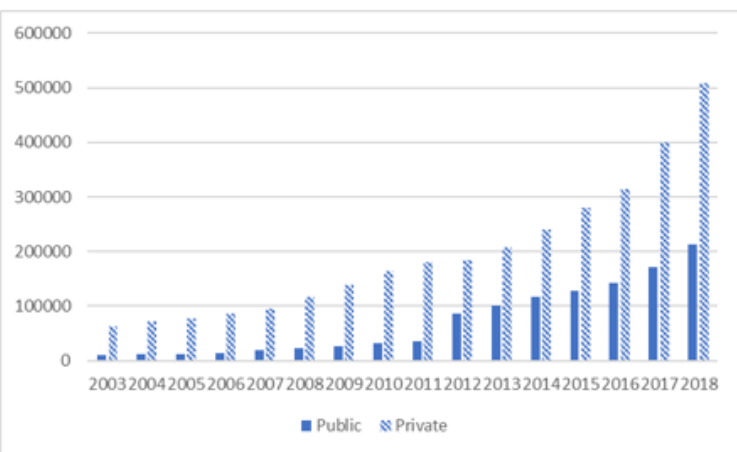

Source: Ministry of Planning and Economic Development.

Figure (10): The Amount of Capital and the Generated Value-Added in the Manufacturing Sector 


\section{The Services Sector}

Through the period 2003-2009, the private companies dominated the number of companies in the services sector by $70 \%$, on average; however, the contribution of the private companies has declined to $47 \%$, on average, during the period 2010-2018, where the number of private companies diminished from 4730 companies in 2003 to 1870 companies in 2018. On the other hand, during the period 2003-2009, the private sector employed $45 \%$, on average, of the labor factor in the services sector, and with the decline in the contribution of the private sector, the percentage of labor factor employed by the private companies diminished by $30 \%$, on average, during the period 2010-2018. In general, the private companies employed around $58 \%$, on average, of the total labor force in the services sector. Regarding the public companies, the size of the public companies retreated by $35 \%$, where the number of public companies decreased from 2957 companies in 2003 to 1960 companies in 2018. However, the public companies occupied a relatively large number of labor-factor during the study period, where the number of labor factors in the public companies has been grown by $25 \%$ during the study period, see figure (11).

Panel (a)

Number of Working Companies

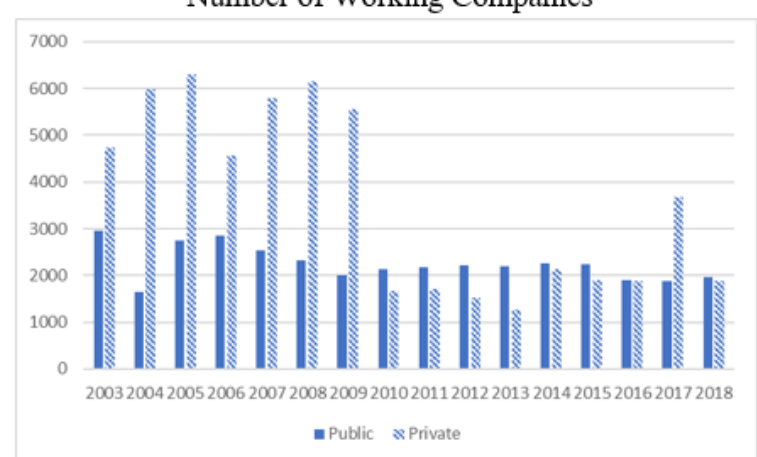

Panel (b)

Number of Labor-Factor

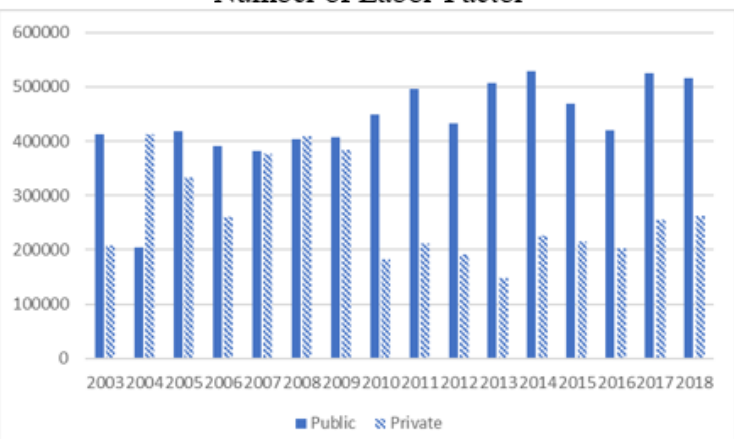

Source: Central Agency for Public Mobilization and Statistics (CAPMS), Employment, Wages and Working Hour Bulletin, different editions

Figure (11): The Number of Companies and Labor factor in the Services Sector

The cost of labor factor in the public companies was higher than its counterpart in the private ones by $24 \%$, where the average wage per week in the public and private agents recorded average rates of 592 EGP and 477 EGP, respectively, during the study period, see figure (12).

Despite the public sector produced just $38 \%$, on average, of the total value-added generated by the services sector; however, the public sector utilized around $54 \%$, on average, of total capital devoted to the services sector. Besides, the growth of the generated value-added

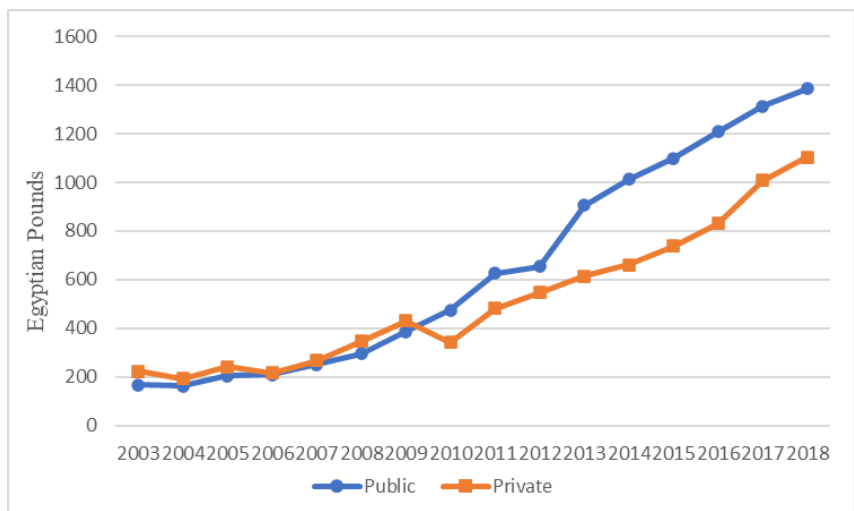

Source: Central Agency for Public Mobilization and Statistics (CAPMS), Employment, Wages and Working Hour Bulletin, different editions.

Figure (12): The Average Wage per Week in the Services Sector was faster in the private sector relative to the public one, where the growth of value-added generated by the public and private companies recorded $15 \%$ and $21 \%$, on average, with standard deviations of $5 \%$ and $13 \%$, respectively, during the study period, see figure (13). 
Panel (a)

Amount of Capital

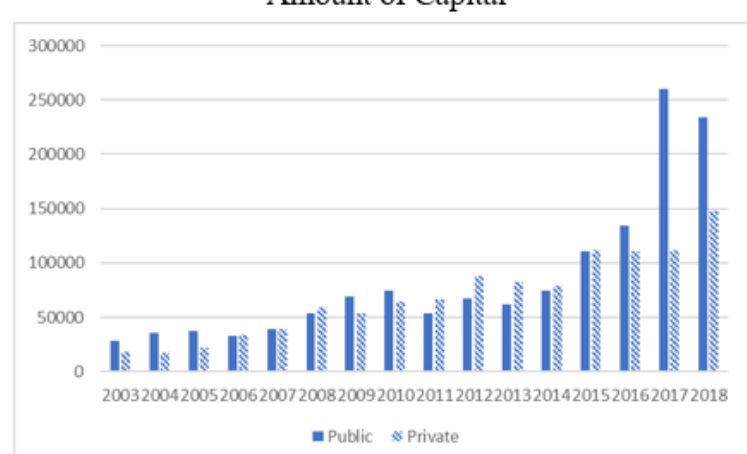

Panel (b)

Generated Value-Added

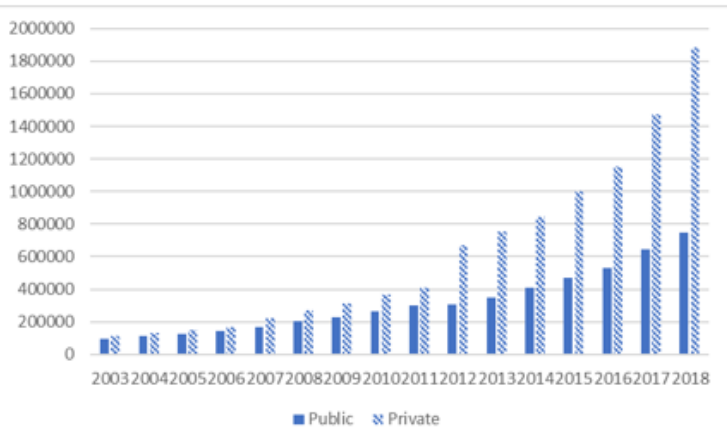

Source: Ministry of Planning and Economic Development.

Figure (13): The Amount of Capital and the Generated Value-Added in the Services Sector

\section{The Technical Efficiency Analysis}

\section{Specifying the Stochastic Frontier Production Function and Model}

The stochastic frontier production function is illustrated as follows: $Y_{n}=f\left(x_{1 n^{\prime}} ; x_{2 n^{\prime}}, \Theta\right)$

Where $\mathrm{Y}$ is the value-added, $\mathrm{X} 1$ is the labor factor, $\mathrm{X} 2$ is the capital factor, and $\Theta$ represents the deviation from the optimal limits (the composed error).

The stochastic model is represented as follows: $\ln Y_{n}=\beta_{0}+\beta_{1} \ln X_{1 n}+\beta_{2} \ln X_{2 n}+v_{n}-u_{n}$

Where $v$ is the random noise term and $u$ is the inefficiency term. $Y_{n}=e^{\left(\beta_{0}+\beta_{1} \ln X_{1 n}+\beta_{2} \ln X_{2 n}\right)} \cdot e^{v i} \cdot e^{-u i}$

Technical Efficiency $(T E)=\mathrm{e}^{-\mathrm{u}}$

The Maximum Likelihood Estimation (MLE) that is developed by Aigner et al. (1977) enables estimating the stochastic frontier as follows:

$$
\ln (\mathrm{Y} \backslash \beta, \sigma, \lambda)=-\frac{N}{2} \ln \left(\frac{\pi \sigma^{2}}{2}\right)+\sum_{n=1}^{N} \ln \phi\left(-\frac{\Theta_{n} \lambda}{\sigma}\right)-\frac{1}{2 \sigma^{2}} \sum_{n=1}^{N} \Theta_{n}^{2}
$$

Where $\sigma^{2}$ is the variance of the composed error $\Theta$ which equals to $\left(\sigma^{2}{ }_{v}+\sigma^{2}\right)$, and $\lambda$ is the ratio of the standard deviation of the inefficiency term to the standard deviation of the noise term $\left(\frac{\sigma_{u}}{\sigma_{v}}\right)$.

Battese and Corra (1977) introduced Gamma $(\gamma)$ as another parameter to determine the share of the inefficiency term in the composed error variance, where Gamma is $\frac{\sigma_{u}^{2}}{\sigma^{2}}$, and always lies within the interval $(0,1)$.

\section{The Production Efficiency of the Private and Public Agents in the Agriculture Sector}

The stochastic frontier analysis revealed that both labor and capital factors are statistically significant, at a $1 \%$ significant level, in determining the value-added in the public agriculture companies. However, the elasticity of capital is greater than the elasticity of labor in determining the value-added, which indicates that the capital factor contributes relatively more than the labor factor to the value-added in the public agriculture companies. The analysis shows that the Gamma statistic is statistically significant, implying that technical inefficiency prevails in the public agriculture sector. In addition, the LR test is 9.191 which is greater than the critical chi-square value of 8.273 at a $1 \%$ significance level. This implies that the null hypothesis of no technical inefficiency has been rejected, see table (1). 
Regarding the private agriculture companies, the contribution of the labor factor is statistically insignificant while the elasticity of the capital factor is positive and statistically significant at a $1 \%$ significance level. This implies that the capital factor is the main contributor to the value-added in the private agriculture companies. Moreover, Gamma is statistically insignificant, indicating that 0.99 of the variability in value-added is attributed to random noises. The LR test is 0.173 which is less than the critical chi-square value of 8.273 at a $1 \%$ significance level. This implies that the null hypothesis of no technical inefficiency has been accepted, see table (2).

According to the previous efficiency analysis, the private agriculture companies are adopting capital intensive techniques, while the public companies are adopting a mixed production technique; however, the response of value-added to the participation of the labor factor is weaker than its response to the participation of the capital-factor. The weak contribution of the labor factor points to the ineligibility of labor to contribute to the agricultural value-added and makes the technical efficiency in the private companies higher than its counterpart in the public one. Moreover, this analysis justifies the dominance of private companies over the agriculture sector.
Table (1): Maximum Likelihood Estimates of the Stochastic Frontier Analysis of the Public Agriculture Sector

\begin{tabular}{ccccc}
\hline Variable & Parameters & Coefficient & $\begin{array}{c}\text { Standard } \\
\text {-Error }\end{array}$ & t-Ratio \\
\hline Constant & Beta 0 & -10.965 & 0.161 & -67.932 \\
\hline Labor-Factor & Beta 1 & 0.863 & 0.00513 & 167.939 \\
\hline Capital-Factor & Beta 2 & 1.111 & 0.0299 & 37.059 \\
\hline Sigma Squared & $\sigma^{2}$ & 1.213 & 0.1246 & 9.7337 \\
\hline Gamma & $\gamma$ & 0.999 & 0.0000025 & 400732 \\
\hline LR Test & 9.191 & & & \\
\hline Log-Likelihood Function & -13.13 & & & \\
\hline $\begin{array}{c}\text { Technical Efficiency } \\
\text { Estimates (mean) }\end{array}$ & 0.58 & & & \\
\hline
\end{tabular}

Source: The outcomes of FRONTIER program Version 4.1

Table (2): Maximum Likelihood Estimates of the Stochastic Frontier Analysis of the Private Agriculture Sector

\begin{tabular}{ccccc}
\hline Variable & Parameters & Coefficient & $\begin{array}{c}\text { Standard } \\
\text {-Error }\end{array}$ & t-Ratio \\
\hline Constant & Beta 0 & 2.1707 & 3.35 & 0.648 \\
\hline Labor-Factor & Beta 1 & 0.1393 & 0.1900 & 0.7332 \\
\hline Capital-Factor & Beta 2 & 0.9958 & 0.2058 & 4.8374 \\
\hline Sigma Squared & $\sigma^{2}$ & 0.1673 & 0.05575 & 3.0018 \\
\hline Gamma & $\gamma$ & 0.0000404 & 0.0805 & 0.000502 \\
\hline LR Test & 0.173 & & & \\
\hline Log-Likelihood Function & -8.401 & & & \\
\hline $\begin{array}{c}\text { Technical Efficiency } \\
\text { Estimates (mean) }\end{array}$ & 0.998 & & & \\
\hline
\end{tabular}

\section{The Production Efficiency of the Private and Public Agents in the Mining Sector}

The contributions of labor and capital to the value-added in the public mining companies show that the elasticity of labor factor is negative and statistically insignificant while the elasticity of capital factor is positive and statistically significant at a $1 \%$ significance level. The Gamma statistic is statistically significant, implying the prevalence of technical inefficiency. However, the LR test is 5.567 which is less than the critical chi-square value of 8.273 at a $1 \%$ significance level. This implies that the null hypothesis of no technical inefficiency has been accepted, see table (3). This may indicate that a moderate technical inefficiency exists in the public mining companies, and the average technical efficiency estimates of 0.723 may support this suggestion.

Table (3): Maximum Likelihood Estimates of the Stochastic Frontier Analysis of the Public Mining Sector

\begin{tabular}{ccccc}
\hline Variable & Parameters & Coefficient & Standard & t-Ratio \\
& & & -Error & -Reta 0 \\
\hline Constant & 7.977 & 0.507 & 1.573 \\
\hline Labor-Factor & Beta 1 & -0.0963 & 0.398 & -0.242 \\
\hline Capital-Factor & Beta 2 & 0.5355 & 0.091 & 5.884 \\
\hline Sigma Squared & $\sigma^{2}$ & 0.2038 & 0.344 & 0.5926 \\
\hline Gamma & $\gamma$ & 0.999 & 0.00372 & 268.33 \\
\hline LR Test & 5.567 & & & \\
\hline Log-Likelihood Function & 0.939 & & & \\
\hline $\begin{array}{c}\text { Technical Efficiency } \\
\text { Estimates (mean) }\end{array}$ & 0.723 & & & \\
\hline Source: The outcomes of FRONTIER program Version 4.1 &
\end{tabular}


The situation is not much different for private mining companies, where the elasticity of the labor factor is negative and statistically insignificant as well. The elasticity of the capital factor is positive and statistically significant at a $1 \%$ significance level. The Gamma statistic is statistically significant. The LR test is 5.193 which is less than the critical chi-square value of 8.273 at a $1 \%$ significance level. Accordingly, the null hypothesis of no technical inefficiency has been accepted. This suggests that a moderate level of technical inefficiency exists in the private mining companies as well, supported by the average technical efficiency estimates 0.731 , see table (4).

\section{The Production Efficiency of the Private and Public Agents in the Manufacturing Sector}

The response of value-added generated by the public manufacturing companies to labor factor is negative and statistically insignificant, while the response to capital factor is positive and statistically significant at a $5 \%$ significance level. The Gamma statistic is statistically insignificant indicating that 0.99 of the changes in value-added is attributed to random noises. The LR test is 0.259 which is less than the critical chi-square value of 8.273 at a $1 \%$ significance level. This implies that the null hypothesis of no technical inefficiency has been accepted, see table (5).

The same findings hold for the private manufacturing companies, where the elasticity of labor factor is negative and statistically insignificant and the elasticity of capital factor is positive and statistically significant at a $1 \%$ significance level. Gamma statistic is statistically insignificant indicating that 0.99 of the changes in value-added is attributed to random noises and just 0.01 of these changes is attributed to technical inefficiency. The LR test is 0.197 which is less than the critical chi-square value of 8.273 at a $1 \%$ significance level. This implies that the null hypothesis of no technical inefficiency has been accepted, see table (6).

The previous analysis indicates that both the private and public manufacturing companies rely on capital-intensive techniques and that the contribution of the labor factor is insignificant. Moreover, the re-
Table (4): Maximum Likelihood Estimates of the Stochastic Frontier Analysis of the Private Mining Sector

\begin{tabular}{ccccc}
\hline Variable & Parameters Coefficient & $\begin{array}{c}\text { Standard } \\
\text {-Error }\end{array}$ & t-Ratio \\
\hline Constant & Beta 0 & -3.461 & 0.45618 & -7.59 \\
\hline Labor-Factor & Beta 1 & -0.1096 & 0.1756 & -6.2408 \\
\hline Capital-Factor & Beta 2 & 1.473 & 0.03584 & 41.1 \\
\hline Sigma Squared & $\sigma^{2}$ & 0.2063 & 0.0496 & 4.155 \\
\hline Gamma & $\gamma$ & 0.999 & 0.00144 & 693.56 \\
\hline LR Test & 5.193 & & & \\
\hline Log-Likelihood Function & 1.24 & & & \\
\hline $\begin{array}{c}\text { Technical Efficiency } \\
\text { Estimates (mean) }\end{array}$ & 0.7313 & & & \\
\hline
\end{tabular}

Table (5): Maximum Likelihood Estimates of the Stochastic Frontier Analysis of the Public Manufacturing Sector

\begin{tabular}{|c|c|c|c|c|}
\hline Variable & Parameters & Coefficient & $\begin{array}{c}\text { Standard } \\
\text {-Error }\end{array}$ & t-Ratio \\
\hline Constant & Beta 0 & 24.085 & 15.803 & 1.524 \\
\hline Labor-Factor & Beta 1 & -1.592 & 1.152 & -1.38 \\
\hline Capital-Factor & Beta 2 & 0.7258 & 0.3221 & 2.253 \\
\hline Sigma Squared & $\sigma^{2}$ & 0.75003 & 0.2651 & 2.829 \\
\hline Gamma & $\gamma$ & 0.0000272 & 0.0169 & 0.001608 \\
\hline LR Test & 0.259 & & & \\
\hline Log-Likelihood Function & -20.401 & & & \\
\hline $\begin{array}{l}\text { Technical Efficiency } \\
\text { Estimates (mean) }\end{array}$ & 0.9964 & & & \\
\hline
\end{tabular}

Table (6): Maximum Likelihood Estimates of the Stochas-

\begin{tabular}{ccccc}
\hline Variable & Parameters Coefficient & $\begin{array}{c}\text { Standard } \\
\text {-Error }\end{array}$ & t-Ratio \\
\hline Constant & Beta 0 & 24.47 & 3.4314 & 7.131 \\
\hline Labor-Factor & Beta 1 & -1.2703 & 0.24474 & -5.190 \\
\hline Capital-Factor & Beta 2 & 0.39419 & 0.09468 & 4.163 \\
\hline Sigma Squared & $\sigma^{2}$ & 0.06006 & 0.02166 & 2.773 \\
\hline Gamma & $\gamma$ & 0.0000488 & 0.048 & 0.001197 \\
\hline LR Test & 0.197 & & & \\
\hline Log-Likelihood Function & -0.204 & & & \\
\hline $\begin{array}{c}\text { Technical Efficiency } \\
\text { Estimates (mean) }\end{array}$ & 0.998 & & & \\
\hline
\end{tabular}

Source: The outcomes of FRONTIER program Version 4.1 tic Frontier Analysis of the Private Manufacturing Sector 
sponse of value-added to capital is more powerful in public companies than in private companies, and both private and public companies are performing at the same level of technical efficiency.

\section{The Production Efficiency of the Private and Public Agents in the Services Sector}

The elasticities of value-added to labor and capital factors are both positive and statistically significant at a $1 \%$ significance level in the public services companies, and the response of value-added to both labor and capital is almost the same. The Gamma statistic is statistically significant, indicating the prevalence of technical inefficiency. The LR test is 5.706 which is less than the critical chi-square value of 8.273 at a $1 \%$ significance level. Accordingly, the null hypothesis of no technical inefficiency has been accepted. This suggests that a moderate level of technical inefficiency exists in the public services companies supported by the average technical efficiency estimates of 0.812 , see table ( 7$)$.

The situation is quite different in the private services companies, where the elasticity of labor factor is negative and statistically insignificant while the elasticity of capital factor is positive and statistically insignificant at a $10 \%$ significance level. The Gamma statistic is statistically insignificant and the LR test is less than the critical chi-square value of 8.273 at a $1 \%$ significance level. This indicates that technical efficiency does not prevail in private services companies.

Table (7): Maximum Likelihood Estimates of the Stochastic Frontier Analysis of the Public Services Sector

\begin{tabular}{ccccc}
\hline Variable & Parameters & Coefficient & $\begin{array}{c}\text { Standard } \\
\text {-Error }\end{array}$ & t-Ratio \\
\hline Constant & Beta 0 & -4.106 & 10.024 & -4.096 \\
\hline Labor-Factor & Beta 1 & 0.70016 & 0.1319 & 5.306 \\
\hline Capital-Factor & Beta 2 & 0.6963 & 0.11319 & 6.1514 \\
\hline Sigma Squared & $\sigma 2$ & 0.0647 & 0.02423 & 2.667 \\
\hline Gamma & $\gamma$ & 0.999 & 0.00611 & 163.567 \\
\hline LR Test & 5.706 & & & \\
\hline Log-Likelihood Function & 7.974 & & & \\
\hline $\begin{array}{c}\text { Technical Efficiency } \\
\text { Estimates (mean) }\end{array}$ & 0.8121 & & & \\
\hline
\end{tabular}

Source: The outcomes of FRONTIER program Version 4.1

Table (8): Maximum Likelihood Estimates of the Stochastic Frontier Analysis of the Private Services Sector

\begin{tabular}{ccccc}
\hline Variable & Parameters & Coefficient & $\begin{array}{c}\text { Standard- } \\
\text { Error }\end{array}$ & t-Ratio \\
\hline Constant & Beta 0 & 0.9316 & 1.00 & 0.9316 \\
\hline Labor-Factor & Beta 1 & -0.132 & 1.00 & -0.1325 \\
\hline Capital-Factor & Beta 2 & 0.1256 & 1.00 & 1.2558 \\
\hline Sigma Squared & $\sigma 2$ & 0.0693 & 1.00 & 0.0693 \\
\hline Gamma & $\gamma$ & 0.1099 & 1.00 & 0.1099 \\
\hline LR Test & 0.000779 & & & \\
\hline Log-Likelihood Function & -0.7677 & & & \\
\hline $\begin{array}{c}\text { Technical Efficiency } \\
\text { Estimates (mean) }\end{array}$ & 0.9339 & & & \\
\hline Source: The outcomes of FRONTIER program Version 4.1 &
\end{tabular}

The previous analysis illustrates that the private services companies are more technically efficient relative to the public services companies; however, the response of valued-added in the public companies to labor and capital is more powerful and effective than in the private services companies.

\section{Concluding Remarks and Recommendations}

The study found differentiated results across the four productive sectors, where the relationship between the weights of public and private agents and the efficiency of their technical performance differ from one sector to another; moreover, the returns and contributions of labor and capital factors to the outputs introduced by the two economic agents differ from one productive sector to another, as well.

\section{Regarding the Agriculture Sector}

The private agents dominant the agriculture sector with noticeable high levels of technical efficiency relative to the public ones, occupying $72 \%$ of agricultural labor at a relatively low cost of labor factor $(-30 \%)$, utilizing $59 \%$ of total capital, and producing $99 \%$ of the value-added generated in the sector. The contribution of labor and capital to value-added is statistically significant in the public sector, while just the contribution of capital is statistically significant in the private sector. 


\section{Regarding the Mining Sector}

The public agents dominant the mining sector with moderate levels of technical efficiency relative to the private ones, occupying $60 \%$ of miners at a relatively low cost of labor factor $(-40 \%)$, utilizing $32 \%$ of total capital, and producing $80 \%$ of the value-added generated in the sector. The contribution of labor to value-added is statistically insignificant in both the public and private sectors, while the contribution of capital is statistically significant in both sectors. However, the response of value-added to capital in the public sector is relatively greater than its response in the private sector.

\section{Regarding the Manufacturing Sector}

The private agents dominant the manufacturing sector with levels of technical efficiency close to the one found in the public ones, occupying $60 \%$ of manufacturing labor at a relatively low cost of labor factor $(-47 \%)$, utilizing $75 \%$ of total capital, and producing $78 \%$ of the value-added generated in the sector. The contribution of labor to value-added is statistically insignificant in both the public and private sectors, while the contribution of capital is statistically significant in both sectors. However, the response of value-added to capital in the public sector is greater than its response in the private sector. This explains how the public sector utilizes just $25 \%$ of total capital and contributes to $22 \%$ of the value-added in the manufacturing sector.

\section{Regarding the Services Sector}

The private agents dominant the services sector with levels of technical efficiency close to the one found in the public ones, occupying $58 \%$ of services labor at a relatively low cost of labor factor (-24\%), utilizing $56 \%$ of total capital, and producing $62 \%$ of the value-added generated in the sector. The contribution of both labor and capital to value-added is statistically significant in the public sector, while their contribution is statistically insignificant in the private one. This explains why the private sector utilizes $56 \%$ of total capital and contributes to just $62 \%$ of the value-added generated in the services sector.

The previous findings confirm the validity of the study hypothesis, where the weights of public and private agents in the different productive sectors are, to a large extent, commensurate with their levels of technical efficiency. It can be said that the previous findings agree with the finding of Husseiny's (2019) study, which argued that the size of the public sector in Egypt is a suitable one and supports the process of economic growth.

In light of the previous findings, we shed light on the following recommendations:

- The quality of labor factor has to be significantly improved through improving the quality of education and healthcare programs. The improvement of the labor factor will not improve just the contribution of labor in the production process but also the contribution of capital as well. Moreover, the improvement of labor is considered one way of utilizing the available endowments of labor in the Egyptian economy, which reduces the gap below the production frontier and increases the levels of efficiency.

- The public agents are able to increase their participation in both the manufacturing and services sector and this will improve the efficiency of the two productive sectors. Moreover, the public agents are adopting production techniques that heavily utilize labor factors, contrary to the private agents which typically adopt capital-intensive production techniques. This makes the increased participation of public agents in the economic growth processes in the interest of the economic development process in Egypt.

- The previous analysis is a quantitative one; accordingly, a qualitative analysis has to be considered along with the quantitative one so that the picture becomes clearer and more complete and the decisions become more effective. This supports future research work on the quality of output produced by the public and private agents. 


\section{References}

Afonso, A. \& Jalles, J. T. (2011). Economic Performance and Government Size. European Central Bank, Working Paper Series, No. 1399.

Agell, J.; Lindh, T. \& Ohlsson, H. (1997). "Growth and the Public Sector: A Critical Review Essay", European Journal of Political Economy, Vol. 13, 33-52.

- $\quad$ Aigner, D. J.; Lovell, C. A. K. and Schmidt, P. (1977). “Formulation and Estimation of Stochastic Frontier Production Function Models", Journal of Econometrics, 6, 21-37. DOI: https://doi.org/10.1016/03044076(77)90052-5

- Aschauer, D. A. (1989). "Is Public Sector Productive?", Journal of Monetary Economics, Vol. 23, pp. 177-200. DOI: https://doi.org/10.1016/0304-3932(89)90047-0

- $\quad$ Battese, G. E. and Corra, G. S. (1977). "Estimation of a Production Frontier Model: with Application to the Pastoral Zone of Eastern Australia", Australian Journal of Agriculture Economics, 21, pp. 169-179. DOI: https://doi.org/10.1111/j.1467-8489.1977.tb00204.x

- Baumol, W. J. (1967). "Macroeconomics of Unbalanced Growth: The Anatomy of Urban Crisis", American Economic Review, 57, pp. 415-26.

- $\quad$ Bella, J. D.; Grant, A.; Kindornay, S.; Tissot, S. \& Slahub, J. E. (2013). The Private Sector and Development: Key Concepts. The North-South Institute.

- $\quad$ Bergh, A. \& Henrekson, M. (2011). “Government Size and Growth: A Survey and Interpretation of the Evidence", Journal of Economic Surveys, Vol. 45, issue 8, Wiley-Blackwell, 1501-1520. DOI: https://doi.org/10.1016/S0014-2921(00)00083-0

- Bogolib, T. M. (2013). "The Public Sector of Mixed Economy in the Modern World. Equilibrium", Quarterly Journal of Economics and Economic Policy, Vol. 8, (1), pp. 125-136. DOI: https://doi. org/10.12775/EQUIL.2013.008

- $\quad$ Demsetz, H. (1967). "Toward a Theory of Property Rights", The American Economic Review, 57, (2), 347-359.

- Ekinci, A. (2011). "What is the Optimum Size of Government: A Suggestion", International Journal of Economics and Finance, Vol. 3, pp. 45-54.

- Evans, P. \& Karras, G. (1994). “Are Government Activities Productive? Evidence from a Panel of U.S. States", The Review of Economics and Statistics, Vol. 76, (1), pp. 1-11. DOI:10.2307/2109821

- Fölster, S. \& Henrekson, M. (2001). “Growth Effects of Government Expenditure and Taxation in Rich Countries", European Economic Review, Vol. 45, pp. 1501-1520.

- García-Sánchez, I.; Cuadrado-Ballesteros, B. \& Frías-Aceituno, J. (2013). “Determinants of Government Effectiveness", International Journal of Public Administration, Vol. 36, pp. 567 - 577. DOI: 10.1080/01900692.2013.772630

- Hall, R. \& Jones, C. I. (1998). “Why Do Some Countries Produce So Much More Output Per Worker than Others?", The Quarterly Journal of Economics, Oxford University Press, Vol. 114, (1), pp. 83-116.

- Harb, N. and Hall, S. J. G. (2017). “Does Government Size Matter for Economic Growth? A Non-Linear Analysis Using State Space Model", https://www.semanticscholar.org/paper/DOES-GOVERNMENT-SIZE-MATTER-FOR-ECONOMIC-GROWTH-A-Harb-Hall/f035fd3527718940926f72d594526337e1f321e9

- Husseiny, I. A. (2019). “The Optimal Size of Government in Egypt: An Empirical Investigation”, The Journal of North African Studies, Vol. 24, pp. 271-299. DOI: 10.1080/13629387.2018.1428798 
Landau, D. (1983). "Government Expenditure and Economic Growth: A Cross-Country Study", Southern Economic Journal, Vol. 49, (3), pp. 783-792. DOI:10.2307/1058716

- Lovre, I.; Ivanovi, O. M. and Miti, P. (2017). "Analysis of Public Sector Efficiency in Developed Countries", Economic Analysis, Vol. 50, No.1-2, pp. 38-49.

- Monte, P. A. (2017). “Public versus Private Sector: Do Workers Behave Differently?", EconomiA, Vol. 18, Issue 2, pp. 229-243. DOI: https://doi.org/10.1016/j.econ.2017.01.001.

- Mueller, D. C. (1987). "The Growth of Government: A Public Choice Perspective”, International Monetary Fund Staff Papers, Vol. 34 (March), pp. 115-149.

- Munnell, A. (1990). "Why Has Productivity Growth Declined? Productivity and Public Investment", New England Economic Review, pp. 3-22.

- Nyasha, S. \& Odhiambo, N. (2019). “Government Size and Economic Growth: A Review of International Literature", SAGE Open, pp. 1-12. DOI: https://doi.org/10.1177/215824401987720

- Orzechowski, W. (1977). "Economic Models of Bureaucracy: Survey, Extension, and Evidence", In: Budgets and Bureaucrats: The Sources of Government Growth, ed. T. E. Borcherding, 237. Chapel Hill: University of North Carolina Press.

- Pejovich, S. (1969). "Liberman's Reforms and Property Rights in the Soviet Union", The Journal of Law and Economics, Vol. 12, pp. 155 - 162.

- Quiggin, J. (1999). "The Future of Government: Mixed Economy or Minimal State?", Australian Journal of Public Administration, Vol. 58, (4), pp. 39-53. DOI: https://doi.org/10.1111/14678500.00126

- $\quad$ Shah, A. \& Huther, J. (1999). "Applying a Simple Measure of Good Governance to the Debate on Fiscal Decentralization", Policy Research Working Paper. Washington, DC: The World Bank. DOI: https://doi.org/10.1596/1813-9450-1894

- $\quad$ Soriano, B. \& Garrido, A. (2015). “The Role of Private Sector in Development: The Relation between Public-Private Investment in Infrastructure and Agricultural Exports in Developing Countries", Economía Agrariay Recursos Naturales. Vol. 15 (2), pp. 93-117. DOI: 10.7201/earn.2015.02.05.

- Thornhill, D. (2006, April). "Productivity Attainment in a Diverse Public-Sector", Presentation at Institute of Public Administration Seminar on Promoting Productivity in a Diverse Public Sector, Dublin.

- UN Millennium Project. (2005). Investing in Development: A Practical Plan to Achieve the Millennium Development Goals. Overview. 